\title{
The role of viruses in Type I diabetes: two distinct cellular and molecular pathogenic mechanisms of virus-induced diabetes in animals
}

\author{
H.S. Jun and J.W. Yoon ${ }^{1}$ \\ ${ }^{1}$ Laboratory of Viral and Immunopathogenesis of Diabetes, Julia McFarlane Diabetes Research Centre, Department of \\ Microbiology and Infectious Diseases, Faculty of Medicine, The University of Calgary, Calgary, Alberta, Canada
}

\section{Abstract}

Type I (insulin-dependent) diabetes mellitus results from the progressive loss of pancreatic beta cells. Environmental factors are believed to play an important part in the development of Type I diabetes by influencing the penetrance of diabetes susceptibility genes. As one environmental factor, the virus has long been considered to play a part in this disease. To date 13 different viruses have been reported to be associated with the development of Type I diabetes in humans and in various animal models. The most clear and unequivocal evidence that a virus induces diabetes in animals comes from studies on the D variant of the encephalomyocarditis (EMC-D) virus in mice and the Kilham rat virus (KRV) in rats. The infection of genetically susceptible strains of mice with a high titre of EMC-D virus results in the development of diabetes within 3 days. This is largely due to the rapid destruction of beta cells by the replication of the virus within the beta cells. In contrast, the infection of mice with a low titre of EMC-D virus results in a limited replication of the virus before the in- duction of neutralizing anti-virus antibody and the subsequent recruitment of activated macrophages. The Src kinases, particularly hck, play an important part in the activation of macrophages and the subsequent production of tumour necrosis factor (TNF)$\alpha$, interleukin (IL)- $1 \beta$ and nitric oxide (NO), leading to the destruction of beta cells which results in the development of diabetes. The Kilham rat virus causes autoimmune diabetes in diabetes resistant (DR)-BB rats without infection of beta cells. The infection of DR-BB rats with KRV results in the disruption of the finely tuned immune balance of Th1-like

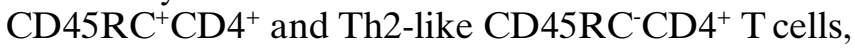
leading to the selective activation of beta-cell-cytotoxic effector T cells. [Diabetologia (2001) 44: 271285]

Keywords Type I diabetes, encephalomyocarditis virus, Kilham rat virus, macrophages, beta-cell-specific autoimmunity, nitric oxide, tumour necrosis factor, Src kinase, haematopoietic cell kinase, beta-cell-cytotoxic effector T cells.
Corresponding author: Prof. Ji-Won Yoon, PhD, Julia McFarlane Diabetes Research Centre, University of Calgary, Faculty of Medicine, 3330 Hospital Drive NW, Calgary, Alberta, T2N 4N1, Canada

The authors contributed equally to the work (co-first authors) Abbreviations: EMC, Encephalomyocarditis; KRV, Kilham rat virus; NO, nitric oxide; VP, viral protein; MAPK, mitogen-activated protein kinase; ERK, extracellular signal regulated kinase; JNK, c-Jun N-terminal kinase; DR-BB, diabetes-resistant BioBreeding; DP-BB, diabetes-prone BioBreeding; RVV, recombinant vaccinia virus; NS, non-structural protein; ConA, concanavalin-A.
Type I (insulin-dependent) diabetes mellitus results from the progressive destruction of insulin-producing pancreatic beta cells, which leads to the development of hypoinsulinaemia and hyperglycaemia [1-8]. It is believed that genetic factors are a major component in the aetiology of Type I diabetes because a strong association has been observed between susceptibility to Type I diabetes and specific alleles of the MHC class II genes [9-17]. Although genetic susceptibility seems to be a prerequisite, studies on the risk of developing Type I diabetes using genetically identical twins have shown that their concordance rate for the 
Table 1. Viruses associated with the development of Type I diabetes

\begin{tabular}{|c|c|c|c|}
\hline Virus & $\begin{array}{l}\text { Nucleic } \\
\text { acid }\end{array}$ & Host & Remarks \\
\hline Coxsackie B & RNA & $\begin{array}{l}\text { Mice } \\
\text { Non-human primates } \\
\text { Humans }\end{array}$ & $\begin{array}{l}\text { Virus was passaged in murine beta cells before infection. } \\
\text { Cytolytic destruction of beta cells leading to Type I diabetes. } \\
\text { Virus was passaged in monkey beta cells before infection. } \\
\text { Development of transient Type I diabetes. } \\
\text { Evidence from epidemiological studies, anecdotal reports. } \\
\text { Virus identified and isolated from pancreas of Type I diabetic pa- } \\
\text { tients shown to be diabetogenic in mice. }\end{array}$ \\
\hline Mengovirus & RNA & Mice & Cytolytic destruction of beta cells. \\
\hline Foot-and-mouth disease virus & RNA & Pigs, cattle & \\
\hline Retrovirus & RNA & Mice & $\begin{array}{l}\text { Beta cell-specific expression of retroviral genes associated with } \\
\text { development of insulitis and Type I diabetes in NOD mice. }\end{array}$ \\
\hline $\begin{array}{l}\text { Bovine viral diarrhoea-mucosal } \\
\text { disease virus }\end{array}$ & RNA & Cattle & Suspected autoimmune responses. \\
\hline Mumps virus & RNA & Humans & Possible induction of islet-cell autoantibodies. \\
\hline Reovirus & RNA & Mice & Possible association with autoimmunity and diabetes in mice. \\
\hline Kilham rat virus & DNA & Rats & $\begin{array}{l}\text { No distinct infection of rat beta cells. } \\
\text { Development of beta-cell-specific autoimmunity, leading to Type I } \\
\text { diabetes. }\end{array}$ \\
\hline Cytomegalovirus & DNA & Humans & Association with autoimmune Type I diabetes. \\
\hline Epstein-Barr & DNA & Humans & Possible induction of autoimmune Type I diabetes. \\
\hline Varicella zoster & DNA & Humans & Indirect evidence of an association with Type I diabetes. \\
\hline
\end{tabular}

disease approaches only about $40 \%$ [18]. This suggests that environmental factors such as viruses, dietary proteins, toxins and stress could be important aetiological determinants $[19,20]$.

Viruses, as an environmental factor, are considered to cause Type I diabetes for several reasons. An apparent seasonal incidence in the onset of acute Type I diabetes with a peak in the autumn was noted almost 70 years ago [21]. Diseases with seasonal incidences are often caused by viral infections. There have also been many anecdotal reports of a viral infection preceding or coinciding with the onset of Type I diabetes, as well as case reports of virus isolation from pancreata of acutely diabetic deceased patients and induction of diabetes in susceptible animals by infection with isolated viruses [22-25]. Epidemiological studies examining newly diagnosed, recent-onset Type I diabetes patients for the presence of virus-specific IgM antibodies have also suggested a role for viruses in the aetiology of Type I diabetes [26-29]. To date, about a half-dozen human viruses have been reported to be associated with human Type I diabetes. These include coxsackie B virus [23, $30,31]$, rubella virus [32,33], mumps virus [34, 35], cytomegalovirus [36-38], Epstein-Barr virus [39, 40] and Varicella Zostar virus [41] (Table 1). In animals, including mice, rats, hamsters, cattle, pigs and nonhuman primates, nine viruses have been reported to be associated with the development of Type I diabetes. Encephalomyocarditis (EMC) virus [42, 43], mengovirus [44], reovirus [45] and retrovirus [46-48] are reported to be associated with Type I diabetes in mice; coxsackie B viruses, particularly B4, in mice $[49,50]$ and non-human primates [51]; foot-andmouth virus in pigs and cattle [52]; rubella virus in hamsters and rabbits [53, 54]; bovine viral diarrheamucosal disease virus in cattle [55]; and KRV in rats [56] (Table 1).

In addition to natural and experimental infection of animals with viruses for the induction of diabetes, a virus-induced transgenic mouse model for studies on Type I diabetes has been developed and studied in depth [57-59]. On the basis of their findings, the authors proposed that an immune response against the determinant shared by the host and virus can evoke a tissue-specific immune response that is capable of eliciting cell and tissue destruction. The possible mechanism is the generation of cytotoxic cross-reactive effector lymphocytes or antibodies that recognize specific determinants on target cells [59].

Viruses can also prevent diabetes. Lymphocytic choriomeningitis virus (LCMV) can prevent the de- 
velopment of autoimmune Type I diabetes in the BioBreeding (BB) rat, a spontaneously diabetic animal model [60] and mouse hepatitis virus (MHV) prevents the development of Type I diabetes in nonobese diabetic (NOD) mice [61].

In both naturally occurring and experimental infection of animals, viruses can be involved in the pathogenesis of Type I diabetes in at least two distinct ways. Firstly, viruses can directly infect and destroy insulin-producing pancreatic beta cells, resulting in Type I diabetes. Secondly, viruses can in some way trigger or contribute to the autoimmune destruction of beta cells. The most clear and unequivocal evidence that a virus induces Type I diabetes in animals comes from studies on EMC virus in mice [42, 43, 62, $63]$ and KRV in rats [56, 64-67]. The EMC-D virus is considered to be a primary agent that is selectively injurious to beta cells, whereas KRV is considered to be a triggering agent of beta cell-specific autoimmunity without the infection of beta cells. This review focuses on the two distinct pathogenic mechanisms for the development of diabetes by these two distinct viruses.

\section{EMC virus-induced diabetes in mice}

The encephalomyocarditis virus, which belongs to the picornavirus family (Piconaviridae), is the smallest single-stranded RNA virus. It is a naked icosahedron and the capsid is composed of a polyprotein, consisting of a single molecule of each of four polypeptides (viral protein [VP]1, 2, 3 and 4). The diabetogenic variant of the EMC virus selectively infects and replicates within the beta cells of genetically susceptible strains of mice. The replication of EMC virus in the beta cells results in macrophages being recruited into the pancreatic islets. The secretion of cytokines, such as interleukin (IL)-1, tumour necrosis factor (TNF)- $\alpha$ and nitric oxide (NO), from the activated macrophages results in the further destruction of the remaining beta cells, leading to diabetes in the mice.

\section{Control of EMC virus-induced diabetes in mice by the viral and host genes}

The $M$ variant of EMC virus (EMC-M) induces a diabetes-like syndrome, characterized by hypoinsulinaemia, hyperglycaemia, glycosuria, polydipsia and polyphagia in genetically susceptible strains of mice [42]. Statistically significant differences in the incidence of diabetes were found between and within experimental groups of mice infected with EMC-M virus $[68,69]$. Plaque purification of EMC-M virus resulted in the isolation of two stable variants, one highly diabetogenic (EMC-D), which produces diabetes in over $90 \%$ of infected animals, and the other non- diabetogenic (EMC-B), which does not produce diabetes in any of the animals it infects [43]. The two variants could not, however, be distinguished antigenically by a sensitive plaque neutralization assay or by competitive radioimmunoassay [43]. Examination of the complete nucleotide sequences of the genomes of both variants showed a total of 14 nucleotide differences between them [70, 71]. Further investigation using several mutant viruses generated from stocks of both EMC-D and EMC-B variants found that only one amino acid, alanine $\left(776^{\text {th }}\right.$ amino acid on the polyprotein), is critical for the diabetogenicity of the EMC virus [72]. A " $G$ " base at nucleotide position 3155 (Ala[GCC]-776 on the polyprotein) is unique to all diabetogenic variants and an "A" base at the same position (Thr[ACC]-776) is identical in all non-diabetogenic variants.

To determine whether the exchange of $\mathrm{Ala}^{776}$ for $\mathrm{Thr}^{776}$, and vice versa, affects viral diabetogenicity, a new recombinant RNA technique was developed involving the creation of a chimeric RNA by attaching the poly $(\mathrm{C})$ region of the viral RNA to the 5 '-truncated RNA transcript of the EMC viral cDNA [73]. Using this technique, site-specific mutagenesis was carried out at nucleotide position 3155 of the EMC viral genome and SJL/J mice were infected with the resulting chimeric EMC viruses. It was found that all of the $\mathrm{Ala}^{776}$-containing recombinant EMC viruses induced diabetes, whereas none of the $\mathrm{Thr}^{776}$-containing recombinant EMC viruses induced diabetes in genetically susceptible mice [74].

To determine whether the substitution of other amino acids for $\mathrm{Ala}^{776}$ had any effect on the diabetogenicity of EMC virus, all possible base permutations of either the first or second base position of codon 776 were constructed using site-specific mutation with appropriate oligonucleotides. These manipulations resulted in EMC viruses with alanine, threonine, serine, proline, aspartic acid or valine at position 776 of the EMC virus polyprotein. None of the viruses, with the exception of those containing $\mathrm{Ala}^{776}$, produced diabetes in infected SJL/J mice (Table 2), indicating the importance of alanine in EMC virus diabetogenicity [74]. Through these studies, it was found that a single amino acid at position 776 of the EMC virus polyprotein determines viral diabetogenicity. The change of a single amino acid $($ Ala $\rightarrow$ Thr $)$ at amino acid position 776 of the polyprotein in diabetogenic EMC virus results in a loss of viral diabetogenicity. Similarly, the change of a single amino acid ( $\mathrm{Thr} \rightarrow \mathrm{Ala}$ ) at the same position in nondiabetogenic EMC virus results in a gain of viral diabetogenicity.

The next question was why the $776^{\text {th }}$ amino acid, Ala, is critical for EMC virus-induced diabetes in mice. This amino acid lies in the highly conserved, strongly hydrophilic patch of the VP1, which contains three proximal prolines (Pro-Thr-Gly-Thr-Pro- 
Table 2. Effects of amino acid substitutions at position 776 of the EMC virus polyprotein on the infection of beta cells and the induction of diabetes in SJL/J mice

\begin{tabular}{|c|c|c|c|c|}
\hline $\begin{array}{l}\text { Amino acid at } \\
\text { position } 776\end{array}$ & Nucleotides $^{\mathrm{a}}$ & $\begin{array}{l}\text { Presence of viral } \\
\text { antigen }^{\text {b }}\end{array}$ & $\begin{array}{l}\text { Glucose index } \\
(\mathrm{mg} / \mathrm{dl}: \text { mean } \pm \mathrm{SD})\end{array}$ & Diabetes $(\%)$ \\
\hline Alanine & $\underline{\mathrm{GCC}}$ & +++ & $407 \pm 98$ & 90 \\
\hline Threonine & $\overline{\mathrm{ACC}}$ & - & $149 \pm 19$ & 0 \\
\hline Proline & $\underline{\mathrm{C}} \mathrm{CC}$ & - & $142 \pm 19$ & 0 \\
\hline Aspartic acid & $\overline{\mathrm{G}} \underline{\mathrm{AC}}$ & - & $169 \pm 21$ & 0 \\
\hline Valine & GT & - & $172 \pm 18$ & 0 \\
\hline
\end{tabular}

a Point mutations at nucleotide position 3155 or 3156 were made with appropriate synthetic oligonucleotides.

${ }^{b}$ At 3 days after infection, sections of pancreas from three randomly selected mice were stained with fluorescein-labelled anti-EMC virus antibody and rhodamine-labelled anti-insulin antibody to determine the presence of viral antigens in beta cells. -, no colocalized fluorescence in the examined islets; +++ , colocalized fluorescence in over $50 \%$ of the examined islets.

${ }^{\mathrm{c}}$ Ten mice per group; $10^{5} \mathrm{PFU}$ of recombinant virus/mouse.
Ala ${ }^{776}$-Lys-Pro). This site has been identified as being involved in viral attachment to beta cells. The aminoacid change from Thr (EMC-B) to Ala (EMC-D) at this position reduces the hydrophilicity of the region by $37 \%$. Thus, this change, unique to the diabetogenic variant, seems to be responsible for the diabetogenicity of the EMC virus by increasing the efficiency of viral attachment to beta cells [75]. This hypothesis is supported by a previous finding [76] that six times more EMC-D virus than EMC-B virus attached to primary beta cells in male ICR Swiss mice.

To test this hypothesis, the binding capability of each of the recombinant chimeric EMC viruses to beta cells was determined. The recombinant chimeric EMC viruses containing Thr, Ser, Pro, Asp or Val at position 152 of the major capsid protein VP1 (amino acid position 776 of the polyprotein) bound poorly to beta cells. In contrast, recombinant chimeric EMC viruses containing Ala at position 152 of the VP1 bound efficiently to and infected $\beta$ cells, resulting in the development of diabetes. Three-dimensional molecular modelling showed that the van der Waals interactions are greater and the residues surrounding position 152 of the VP1 are more closely packed in recombinant chimeric viruses containing Thr, Ser, Pro, Asp or Val at position 152 than in recombinant chimeric viruses containing Ala at the same position (Fig. 1). The surface area surrounding Ala at position 152 of the VP1 is more accessible, thus increasing the availability of the binding sites for attachment to beta-cell receptors and resulting in viral infection and the development of diabetes [77].

With respect to the genetic control of EMC virusinduced diabetes, only certain inbred strains of mice (SJL, SWR, DBA/1, DBA/2) develop diabetes, whereas other strains (C57BL/6, CBA, AKR, $\mathrm{BALB} / \mathrm{C}$ ) do not develop diabetes when infected with the EMC-M virus [78]. Susceptibility seems to be inherited as an autosomal recessive trait, because the F1 cross between diabetes-prone SWR/J mice and diabetes-resistant C57BL/6J mice was resistant to diabetes on infection with EMC virus, whereas more than $20 \%$ of the $\mathrm{F} 2$ generation contracted diabetes on exposure to the virus. When resistant F1 generations were back-crossed with the resistant C57BL/6J parents, the resulting offspring were also resistant to the development of EMC virus-induced diabetes. In contrast, when the resistant F1 generation was back-crossed with the susceptible SWR/J parents, approximately $50 \%$ of the resulting offspring contracted diabetes. The data are consistent with the idea that EMC virus-induced diabetes follows Mendelian inheritance and that susceptibility is controlled by a single locus [78]. More recent experiments, in combination with earlier data, have indicated that a single gene controlling susceptibility to EMC-D virus-induced diabetes in mice can operate by modulating the expression of viral receptors on the beta cells [79].

\section{Pathogenic mechanism of EMC-D virus-induced diabetes in mice}

Earlier studies showed that the infection of a genetically susceptible mouse strain (i.e. SJL/J) with a high titre $\left(5 \times 10^{5}\right.$ plaque-forming units [PFU]/mouse $)$ of EMC-D virus results in the development of diabetes within 3 days due to the rapid destruction of beta cells by viral replication in the cells before the induction of sufficient neutralizing antibody against EMC-D virus [43]. To determine whether T-cell suppression has any effect on EMC-D virus-induced diabetes, SJL/J mice were treated with anti-L3T4 antibody or antiLyt 2 antibody or both before and after EMC-D virus infection $\left(5 \times 10^{5} \mathrm{PFU} / \mathrm{mouse}\right)$. There was no statistically significant difference in the incidence of diabetes between the anti- $T$ cell antibody-treated and untreated animals $[80,81]$. To determine whether macrophages play any part in the destruction of beta cells in EMC-D virus-infected mice, SJL/J mice were treated with anti-macrophage antibody (anti-Mac-2) before and after EMC-D viral infection $\left(1 \times 10^{5}\right.$ PFU/mouse). The incidence of virus-induced diabe- 

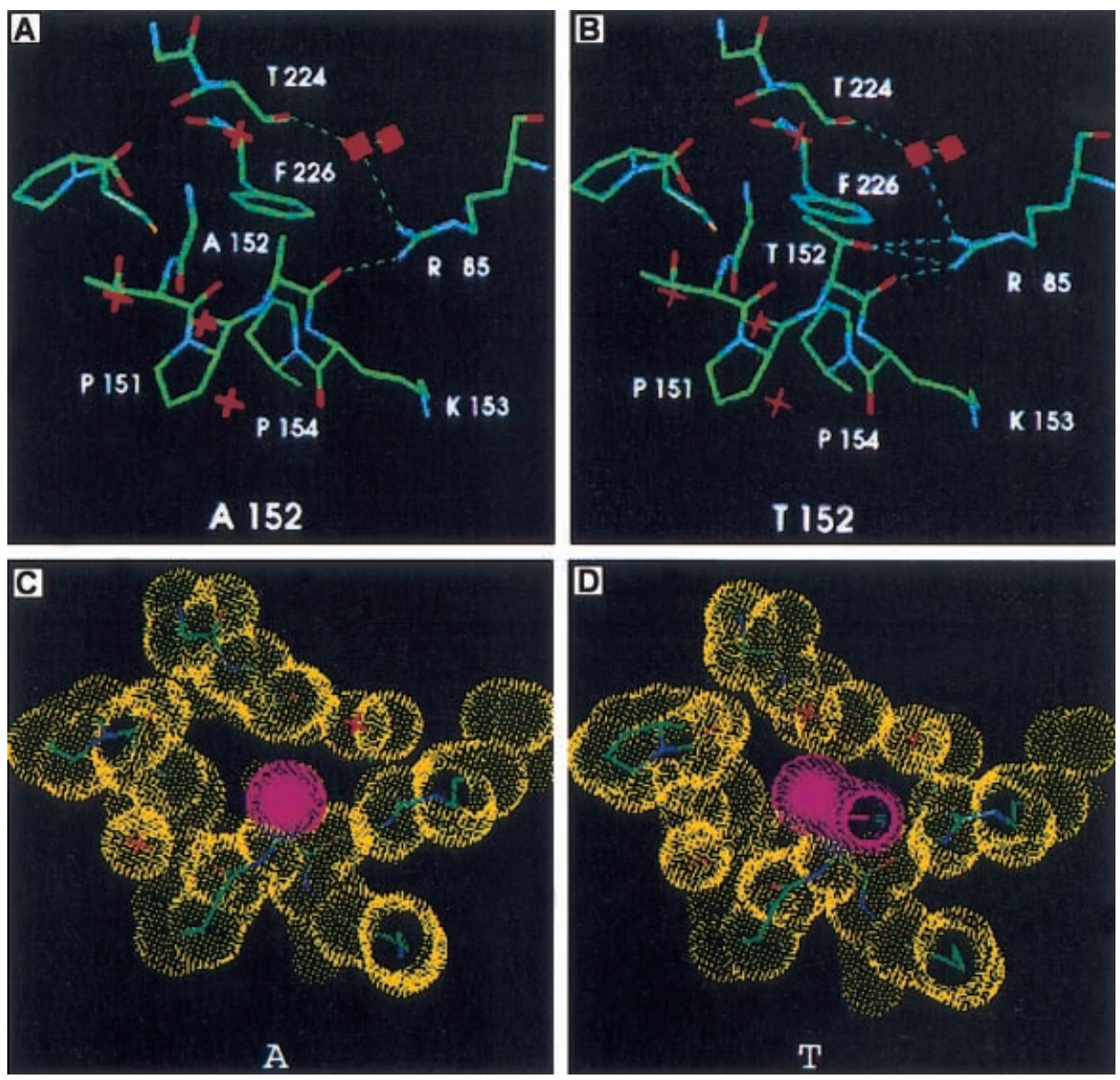

Fig. 1A-D. Molecular differences between diabetogenic EMC-D virus and non-diabetogenic EMC-B virus. Models of the capsid protein VP1 of $\mathrm{Ala}^{152}$-containing EMC-D virus (A152) (A) and $\mathrm{Thr}^{152}$-containing EMC-B virus (T152) (B). A view of the atoms in the region surrounding the $152^{\text {nd }}$ amino acid are shown. The Ala ${ }^{152}$ mutation at the $152^{\text {nd }}$ position of the VP1 result in the loss of two hydrogen bonds with $\mathrm{Arg}^{85}$. Nitrogen atoms are depicted in blue, oxygen in red and protein carbon in green. The image was generated with the Insight II program, version 2.3.5 (Biosym Technologies, San Diego, Calif., USA). A van der Waals surface comparison of Ala ${ }^{152}$-containing EMC-D virus $(\mathbf{C})$ and $\mathrm{Thr}^{152}$-containing EMC-B virus (D). The van der Waals forces could be stronger and the accessible surface area smaller in the capsid protein VP1 of Thr ${ }^{152}$. containing EMC viruses. The loosely packed residues surrounding $\mathrm{Ala}^{152}$ in EMC viruses might permit recognition by beta-cell receptors. The images were generated with the Insight II program

tes in mice treated with anti-macrophage antibody was lower than that in the untreated mice, indicating that macrophages play an important part in the process of beta cell destruction in the EMC-D virus-infected SJL/J mice [81]. Natural viral infections in animals and humans generally involve, however, exposure to relatively low numbers of virus; exposure to the high viral titres used in the experiments described above would not be likely in nature. Thus, another animal model was established to study the immune mechanisms involved in the destruction of beta cells, in which mice were infected with a low dose (100 PFU/mouse) of EMC-D virus [82].

In mice infected with a low dose of EMC-D virus, macrophages play a central part in the destruction of beta cells, as activation of macrophages before viral infection results in a statistically significant increase in the incidence of diabetes and inactivation of macrophages before viral infection almost completely prevents EMC-D virus-induced diabetes [82]. Additional studies showed that the selective EMC-D viral infection of pancreatic beta cells results in an initial recruitment of macrophages into the islets (Fig. 2), followed by infiltration by other immunocytes including T cells, natural killer (NK) cells and B cells [81]. Although these studies show that macrophages are involved in the destruction of beta cells, the part played by macrophages is not fully understood. Further study found that EMC-D virus infects macrophages and activates them, but does not replicate within the macrophages [83]. Because macrophages are known to produce soluble mediators, IL-1 $\beta$, TNF- $\alpha$ and NO, the involvement of these mediators in the destruction of beta cells in mice infected with a low dose of EMC-D virus was investigated. The expression of IL-1 $\beta$, TNF- $\alpha$ and inducible nitric oxide synthase (iNOS) was selectively detected in the pan- 

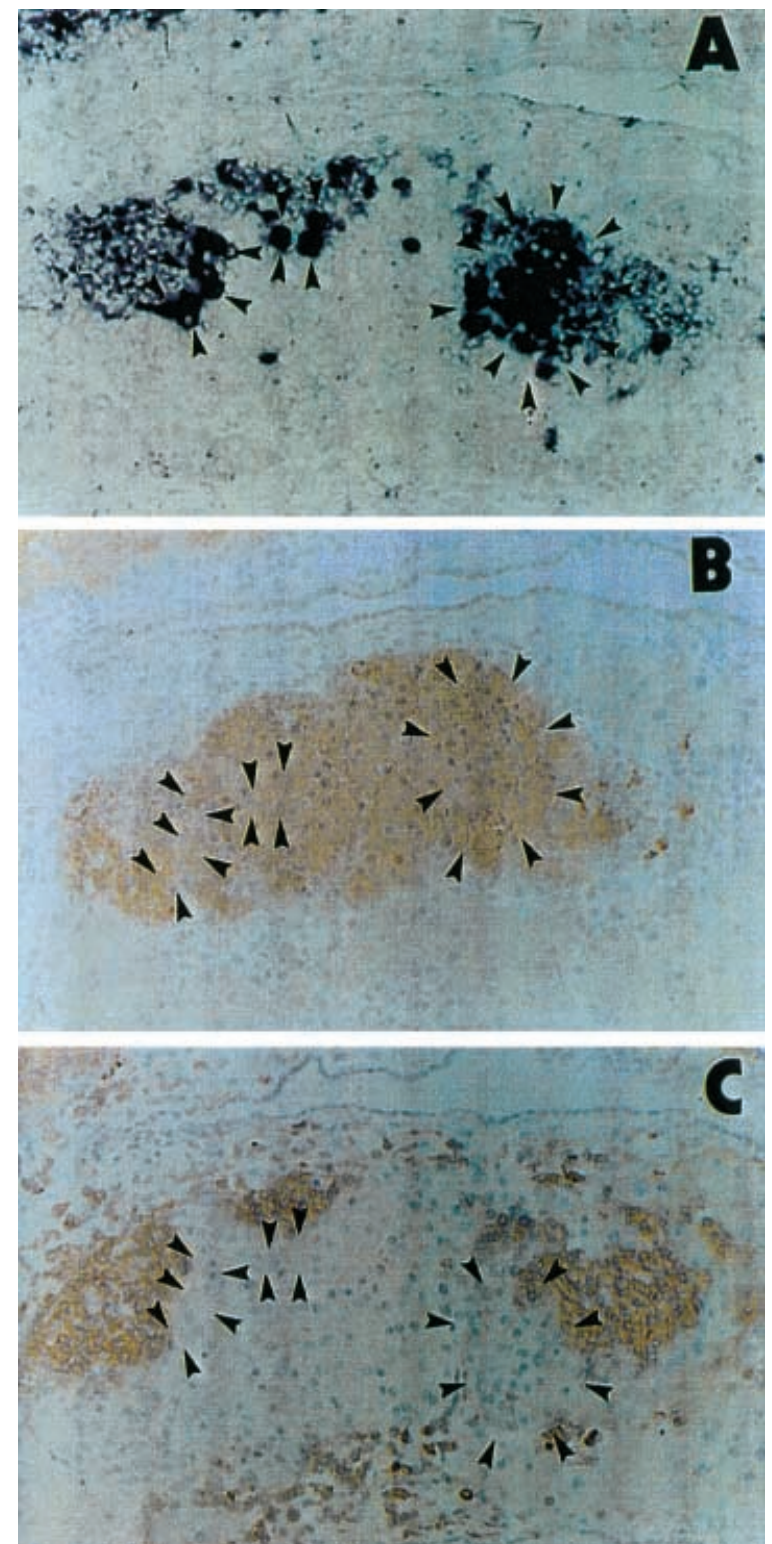

Fig. 2 A-C. Expression of EMC-D viral genes in pancreatic beta cells and infiltrated macrophages. Serial sections of pancreatic islets were prepared from DBA/2 mice at 3 days after infection with EMC-D virus, hybridized with the antisense RNA probe of EMC-D virus $(\mathbf{A})$ and stained with anti-insulin antibody (B) or anti-macrophage antibody $(\mathbf{C})$. Beta cells are heavily infected (dark blue color surrounded by arrows, A and B), whereas macrophages are lightly infected with EMC-D virus (peripheral areas of the islets with arrows, $\mathbf{A}$ and $\mathbf{C}$ ). Arrowheads indicate corresponding locations between sections

creatic islets of mice infected with a low dose of EMC-D virus. In addition, the treatment of EMC-D virus-infected mice with antibody against IL- $1 \beta$ or TNF- $\alpha$ or with the iNOS inhibitor, aminoguanidine, resulted in a significant decrease $(p<0.01)$ in the incidence of diabetes [84]. These results suggest that macrophage-derived soluble mediators play a critical part in the destruction of beta cells, leading to the de- velopment of diabetes in mice infected with a low dose of EMC-D virus. The molecular mechanism involved in the destruction of beta cells by these soluble mediators is, however, not known. Investigators have shown that IL- $1 \beta$ induces apoptosis through the induction of inducible nitric oxide synthase (iNOS) expression and NO production in rat islet cells [85-87]. Both IL- $1 \beta$ and TNF- $\alpha$ have been shown to increase the expression of Fas, which is involved in apoptosis [88]. Therefore, it is possible that the limited replication of EMC-D virus in beta cells results in the recruitment of macrophages activated by virus infection, and IL- $1 \beta$ and TNF- $\alpha$, produced by activated macrophages in the pancreatic islets, induce the expression of Fas in the beta cells and/or induce iNOS expression and NO production that contribute to beta-cell death through apoptosis (Fig. 3).

The above studies showed that macrophages activated by EMC-D virus produce the soluble mediators that play an important part in the destruction of beta cells. The mechanisms that activate macrophages are, however, not known. Further investigations were initiated to determine whether a tyrosine kinase signalling pathway might be involved in the EMC-D virus-induced activation of macrophages in vitro and, if so, whether treatment with a tyrosine kinase inhibitor in vivo might protect against EMC-D virusinduced diabetes. Inducible NOS was expressed at a higher level than either IL- $1 \beta$ or TNF- $\alpha$ in cultured macrophages activated by EMC-D virus. There was also high NO production in these macrophages but there was no progeny virus production [83]. These results suggest that EMC-D viral infection of macrophages does not produce progeny virus but could result in the activation of macrophages. The production of NO was clearly inhibited by the addition of tyrosine kinase inhibitors such as AG126. When the tyrosine phosphorylation of mitogen-activated protein (MAP) kinases, such as extracellular signal-regulated kinases (ERK) 1/2, p38 MAPK and c-Jun-terminal activation kinase (JNK), was examined in macrophages infected with EMC-D virus, it was found that these signalling molecules were clearly activated $5 \mathrm{~h}$ after infection.

Next, the effect of AG126 on the development of diabetes was examined in DBA/2 mice infected with a low dose of EMC-D virus. The incidence of diabetes decreased greatly in mice treated with AG126. In contrast, a related tyrosine kinase inhibitor, AG556, which failed to suppress the production of NO in infected macrophages in vitro, failed to prevent diabetes when given to EMC-D virus-infected DBA/2 mice [83]. Thus, the suppression of macrophage-derived $\mathrm{NO}$ in vitro and the prevention of diabetes are strongly correlated. The expression of IL- $1 \beta$, TNF- $\alpha$ and iNOS in the pancreata of AG126-treated, EMC$\mathrm{D}$ virus-infected DBA/2 mice was further analysed and it was found that the expression of these mRNAs 
Low dose of EMC-D virus

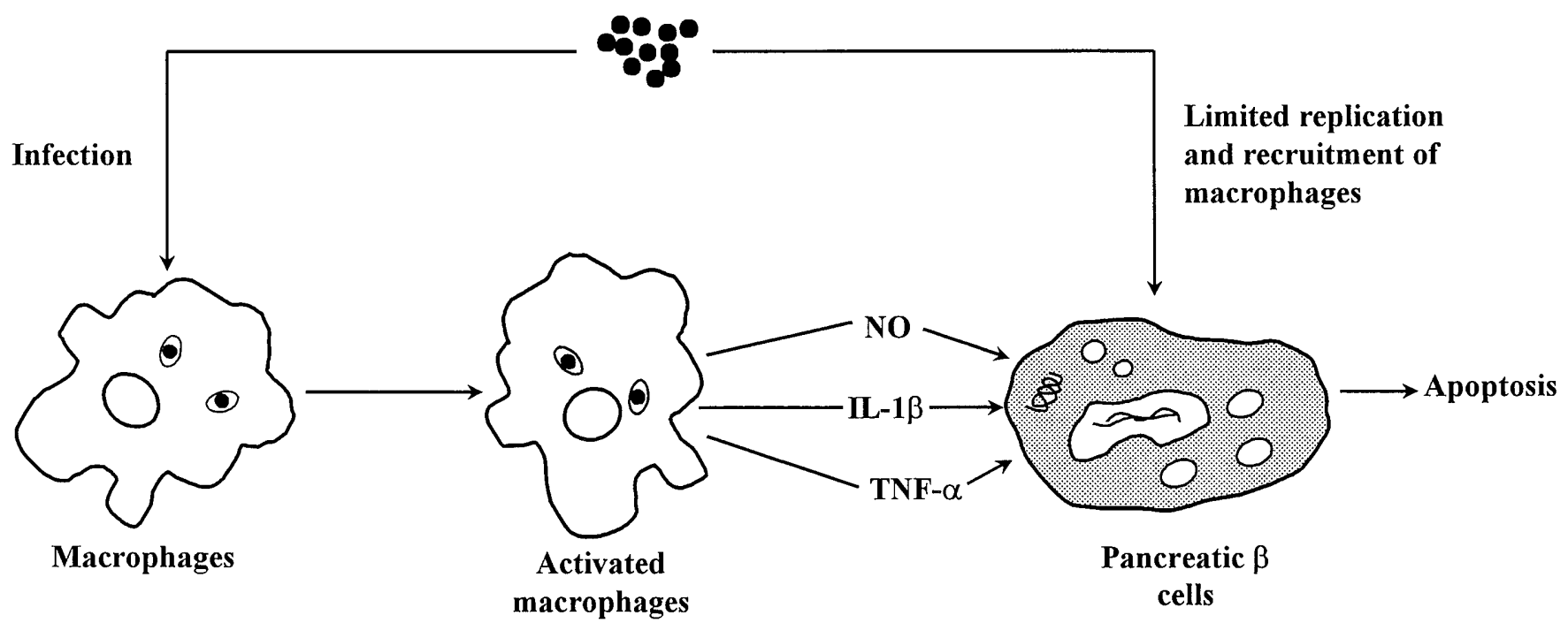

Fig. 3. Possible mechanism for macrophage-mediated betacell destruction in mice infected with a low dose of EMC-D virus. The selective infection of beta cells with EMC-D virus results in an initial recruitment of EMC-D virus-induced activated macrophages into the pancreatic islets. The activated macrophages secret IL-1beta, TNF- $\alpha$ and NO, which may kill the beta cells through apoptosis

was clearly suppressed in the pancreata of AG126treated mice compared with vehicle-treated control mice [83]. This result indicates that the treatment of EMC-D virus-infected mice with a tyrosine kinase inhibitor (AG126) not only suppresses the expression of iNOS but also inhibits macrophage-derived cytokines such as IL- $1 \beta$ and TNF- $\alpha$.

To further explore the signalling mechanisms in the activation of macrophages by EMC-D virus, the expression and activation of signal transduction molecules, particularly the Src family of tyrosine kinases including $\mathrm{p} 53 / 56^{\mathrm{lyn}}, \mathrm{p} 58 / 64^{\mathrm{hck}}$ and $\mathrm{p} 59^{\mathrm{c}-\text {-fgr }}$, were examined in peritoneal macrophages from $\mathrm{DBA} / 2$ mice infected with a low dose of EMC-D virus. Of the Src family kinases tested, hck showed a large increase in autophosphorylation and phosphorylation of Sam 68 (a substrate for Src kinase) (Fig. 4). In contrast to hck, the autophosphorylating activity of lyn and fgr were barely detected and phosphorylation of Sam 68 was not increased. The protein content of hck had a peak at $48 \mathrm{~h}$ after the infection of EMC-D virus (Fig.4). These results suggest that hck is involved in the activation of macrophages in mice infected with EMC-D virus. In addition, whether the tyrosine phosphorylation of hck contributes to hck activity was examined by western blot analysis of hck in immune complex precipitated with anti-phosphotyrosine antibody. It was found that tyrosine phosphorylation of hck peaked $48 \mathrm{~h}$ after infection, with the same kinetics as that of hck activity. Next, the tyrosine phospho- rylation level of an adaptor protein, Vav, was examined at the time of the highest kinase activity of hck (at $48 \mathrm{hr}$ after EMC-D virus infection), as hck is believed to mediate tyrosine phosphorylation of Vav. The tyrosine phosphorylation of Vav was increased at $48 \mathrm{~h}$ after viral infection. These results suggest that hck signalling plays a critical part in the activation of macrophages through the mediation of the adaptor protein, Vav, in mice infected with EMC-D virus.

On the basis of these observations, it is hypothesized that the infection of macrophages by EMC-D virus results in the activation of Src kinase, particularly hck. Src kinase might activate the MAP kinase signalling pathway through Raf, MEK1/2 and ERK1/2, MKK4 and JNK, or MKK and p38MAPK. It is also possible that ERK1/2 and $\mathrm{JNK}$ activate I $x \mathrm{~B}$ kinase, resulting in $\mathrm{I} \varkappa \mathrm{B}$ degradation and the activation of the transcription factor NF $\mathrm{B}$. Furthermore, JNK could activate the transcription factor c-Jun, and p38MAPK could activate the transcription factor AP-1. The activated transcription factors bind to the appropriate site of the promoter region for IL- $1 \beta$, TNF- $\alpha$ or iNOS and stimulate the transcription of these genes (Fig. 5). The soluble mediators (i.e., IL$1 \beta$, TNF- $\alpha$, NO) produced by the activation of these genes work synergistically to kill beta cells by apoptosis leading to diabetes in genetically susceptible mice infected with a low dose of the EMC-D virus.

\section{KRV-induced autoimmune diabetes in rats}

The Kilham rat virus belongs to the parvovirus family. The parvovirus virion has a diameter of 18 to 26 $\mathrm{nm}$ and a relatively simple structure composed of three proteins and a linear, single-stranded DNA molecule. Parvoviruses replicate in the nucleus of dividing cells - hence the predilection of these viruses 


\section{A. Kinase Assay}
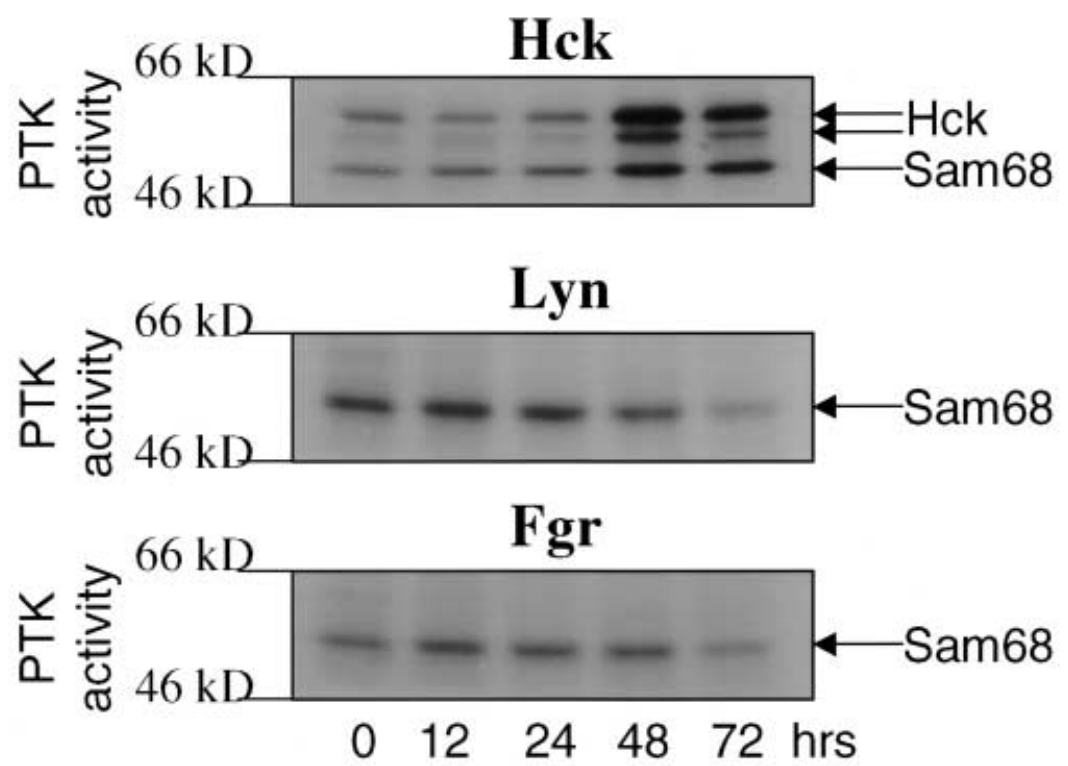

\section{B. Western Blot}

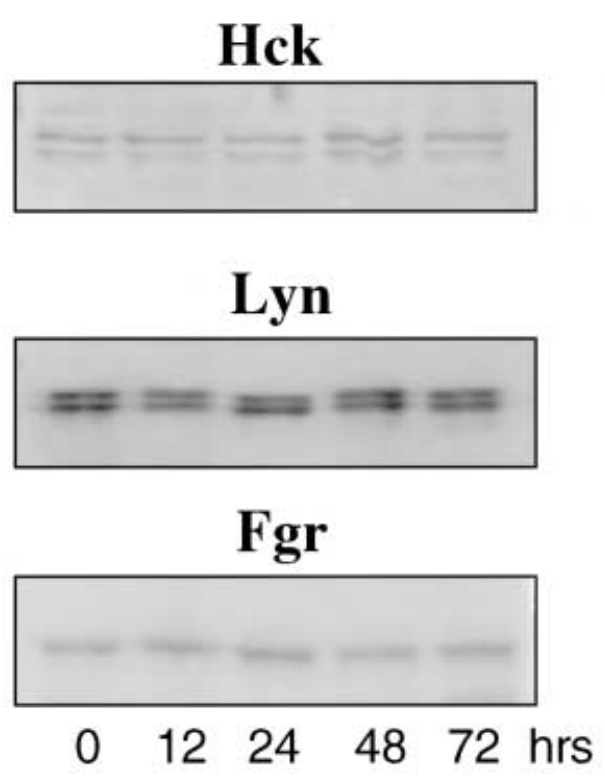

Fig. 4A, B. Kinase activities of immunoprecipitated hck, lyn and fgr and their expression in macrophages from mice infected with EMC-D virus. (A) Immune complex kinase assay. Cell extracts were prepared from isolated macrophages after virus infection at the indicated time points. The activated hck, lyn or fgr was immunoprecipitated with anti-hck, anti-lyn or anti-fgr antibodies, respectively, and an in vitro kinase assay was carried out in the presence of recombinant Sam68 as substrate. (B) Immunoblot of whole cell lysates of macrophages from mice infected with EMC-D virus. Cell extracts were prepared from the isolated macrophages at the indicated times after virus infection and the expression of the Src family kinases was measured by immunoblotting with specific antibodies

for bone marrow, lymphoid organs, gut and the developing embryo - and the genome becomes integrated with that of the infected cell. The KRV was originally isolated from a rat sarcoma and has been found to cause a fatal neonatal disease, physical deformities and mental retardation in newborn rats.

The KRV has been shown to cause autoimmune diabetes in diabetes-resistant BioBreeding (DR-BB) rats, without distinct infection of beta cells [56, 64]. Diabetes-prone (DP) BB rats, like NOD mice, spontaneously develop a diabetic syndrome that resembles human Type I diabetes in many respects [89]. The DP-BB rats are lymphopenic and $70-80 \%$ of the animals become diabetic at about 120 days of age. In contrast to DP-BB rats, DR-BB rats, derived from DP progenitors, have normal lymphocyte numbers and phenotypes and usually do not develop diabetes. When 21 to 25 -day-old DR-BB rats were infected with KRV, about $30 \%$ of the animals developed autoimmune diabetes within 2-4 weeks after in- fection [56]. An additional 31\% showed evidence of lymphocytic insulitis without diabetes.

\section{Role of macrophages in $K R V$-induced diabetes in $D R-B B$ rats}

The infection of beta cells is an absolute requirement for the development of EMC-D virus-induced diabetes in mice. In contrast, KRV can induce autoimmune diabetes in DR-BB rats without the infection of beta cells. The KRV infects lymphoid organs such as the spleen, thymus and lymph nodes. Diabetes-resistant $\mathrm{BB}$ rats harbour autoreactive T cells, which are naturally held silent by immunoregulatory control involving the RT6.1 ${ }^{+}$subset of T cells $[90,91]$. Recent experimental data suggests that KRV infection leads to the activation of silent autoreactive T cells in DR-BB rats [65]. These activated T cells are thought to be specific for beta cells. The precise mechanisms by which KRV induces autoimmune Type I diabetes without the infection of beta cells are, however, poorly understood.

Recent investigation sought to determine whether macrophages and macrophage-derived cytokines play any part in the development of KRV-induced diabetes in DR-BB rats [66]. The inactivation of macrophages with liposomal dichloromethylene diphosphonate (lip- $\mathrm{Cl}_{2} \mathrm{MDP}$ ), which is selectively toxic to macrophages, results in the near complete prevention of insulitis and diabetes in KRV-infected DR-BB rats. Measurement of the macrophage-derived cytokines IL-12, TNF- $\alpha$ and IL- $1 \beta$ showed a selective increase in expression after KRV infection in the splenic lymphocytes and pancreatic islet infiltrates. Measurement of $\mathrm{CD}^{+}{ }^{+} \mathrm{T}$ cell-derived cytokines found that 


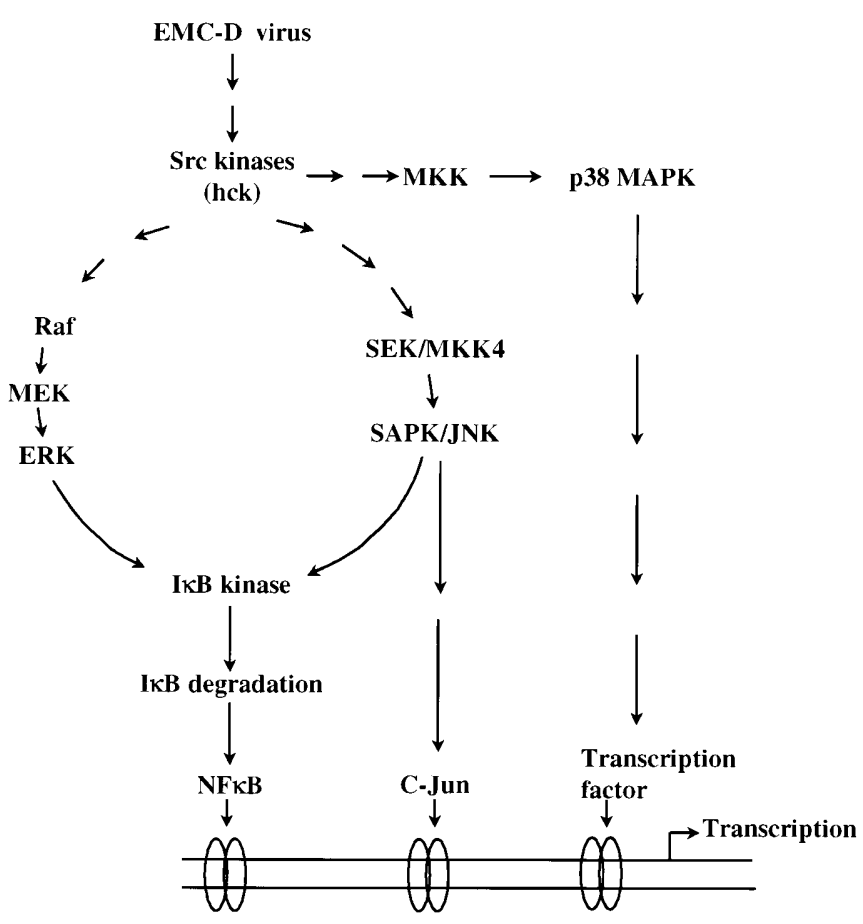

Fig. 5. Schematic diagram of the proposed signal transduction pathway involved in the EMC-D virus-induced activation of macrophages. The infection of macrophages by EMC-D virus could result in the activation of Src kinase, particularly hck. The Src kinases could activate the MAP kinase signaling pathway via Raf, MEK1/2 and ERK1/2 or via MKK4 and JNK or via MKK and p38 MAPK. ERK1/2 and JNK could activate $\mathrm{I} \varkappa \mathrm{B}$ kinase, resulting in $\mathrm{I} \varkappa \mathrm{B}$ degradation and activation of the transcription factor, NF $x \mathrm{~B}$. JNK could also activate the transcription factor c-Jun and p38 MAPK could activate the transcription factor AP-1. The activated transcription factors bind to the appropriate site of the promoter region for IL- $1 \beta$, TNF$\alpha$ and iNOS, and stimulate the transcription of these genes

IL-2 and interferon (IFN)- $\gamma$ cytokine gene expression are closely correlated with an increase in the gene expression of IL-12 but that IL-4 and IL-10 gene expression did not change. An imbalance between the Th1-type $\mathrm{CD}^{+}$and Th2-type $\mathrm{CD}^{+}$subsets is thought to play an important part in the development of autoimmune responses to beta cells. The expression of Th1-type cytokines, such as IL- 2 and IFN- $\gamma$, correlates with the development of autoimmune diabetes, whereas the expression of Th2-type cytokines, such as IL-4, correlates with the prevention of diabetes. The increased expression of Th1-type cytokines, but not Th2-type cytokines, observed in KRV-infected DR-BB rats could be the result of a selective increase in the expression of IL-12 produced by activated macrophages. To determine whether macrophages are essential for the initiation of KRV-induced diabetes in DR-BB rats, adoptive transfer experiments were undertaken. Concanavalin-A (ConA)-activated splenic lymphocytes isolated from macrophage-depleted DR-BB rats injected with KRV/poly I:C did not induce insulitis and diabetes in young DP-BB rats, indicating that the depletion of macrophages resulted in the loss of the ability to transfer diabetes. These studies show that macrophages and macrophage-derived cytokines play a critical part in the cascade of events leading to the destruction of beta cells, culminating in the development of autoimmune diabetes in KRV-infected DR-BB rats.

\section{Role of Tcells in KRV-induced autoimmune diabetes in DR-BB rats}

It was still not clear how KRV causes the destruction of beta cells in DR-BB rats without infection of these cells. Molecular mimicry, such as the existence of a common epitope between a KRV-specific peptide and a beta-cell autoantigen, has been suggested as a mechanism for the initiation of beta-cell-specific autoimmune diabetes $[56,66]$. If molecular mimicry is involved in the initiation of beta-cell-specific autoimmunity, then KRV antigen-specific T cells generated by KRV peptides might cross-react with beta cells and attack them, resulting in the development of insulitis and, subsequently, diabetes. To test this hypothesis, recombinant vaccinia virus (rVV) expressing KRV proteins was used because the wild-type strain of vaccinia virus does not induce insulitis or diabetes in DR-BB rats [56] and rVVs have been used as a vehicle for the expression of foreign proteins that successfully induced humoral and cell-mediated immune responses [92-94]. The rVVs expressing the KRV peptides VP1, VP2 (completely overlapped by VP3), non-structural protein (NS)1 or NS2 were constructed. When DR-BB rats were infected with the rVVs expressing the KRV peptides, it was found that each viral peptide was clearly expressed in the infected DR-BB rats, viral peptide-specific $T$ cells were generated, and antibodies against the KRV peptides were also induced. None of the DR-BB rats, however, developed insulitis or diabetes [67]. This result indicates that molecular mimicry between KRV peptides and beta-cell-specific autoantigens in DR-BB rats is unlikely to be a mechanism by which KRV induces beta-cell-specific autoimmune diabetes.

Because the KRV proteins failed to induce autoimmune diabetes in DR-BB rats, an alternative hypothesis is that KRV infection of DR-BB rats disturbs the finely tuned immune balance and activate autoreactive T cells that are cytotoxic to beta cells, resulting in T-cell mediated autoimmune diabetes similar to that seen in DP-BB rats. To test this hypothesis, the $\mathrm{CD}^{+}$and $\mathrm{CD} 8^{+} \mathrm{T}$ cell populations were examined in the splenocytes of DR-BB rats after KRV infection. The percentage of $\mathrm{CD}^{+} \mathrm{T}$ cells increased considerably, whereas the percentage of $\mathrm{CD}^{+} \mathrm{T}$ cells decreased, although the absolute number of both $\mathrm{CD}^{+}$ and $\mathrm{CD} 8^{+} \mathrm{T}$ cells was increased during KRV infec- 
A

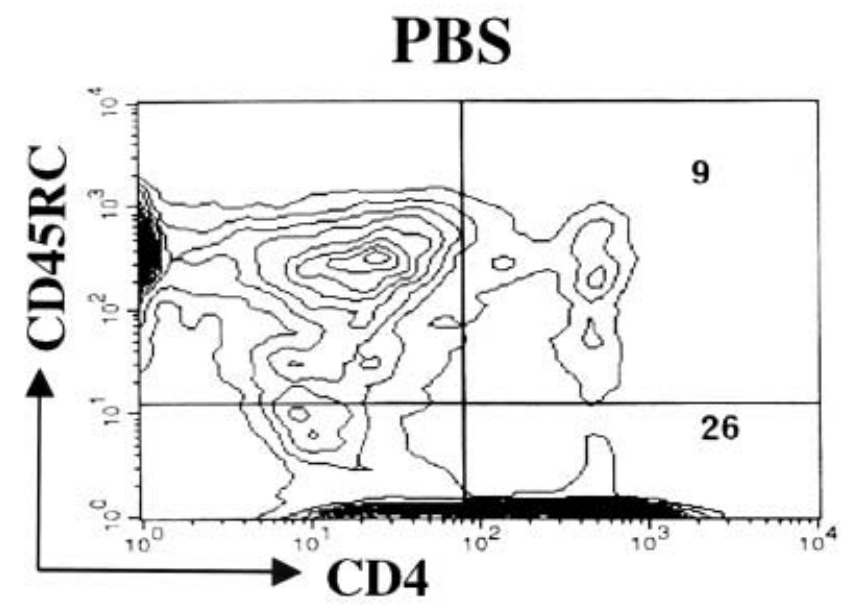

KRV

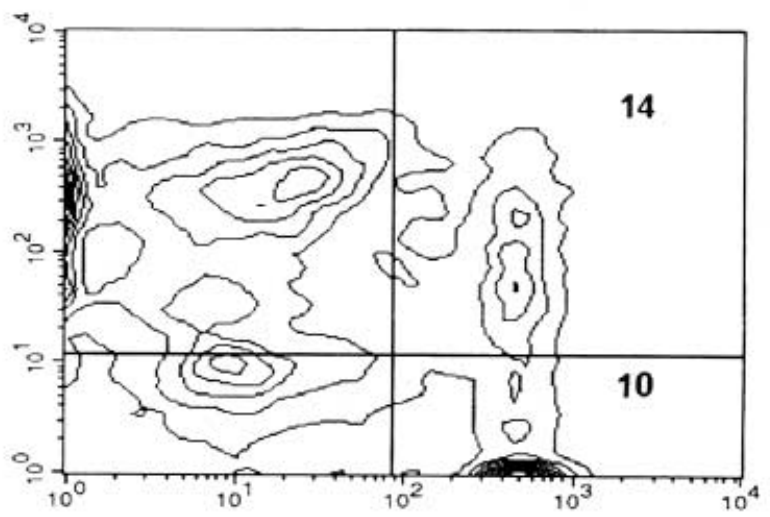

B

CD45RC-CD4+ T cells

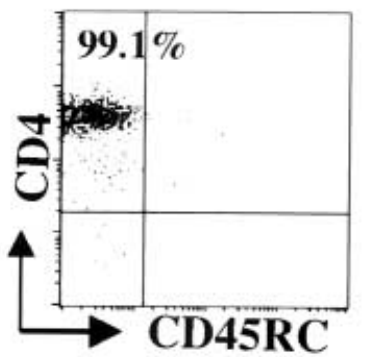

CD45RC+CD4+ T cells

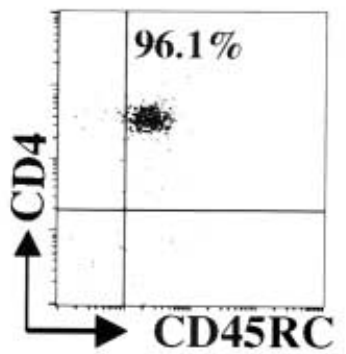

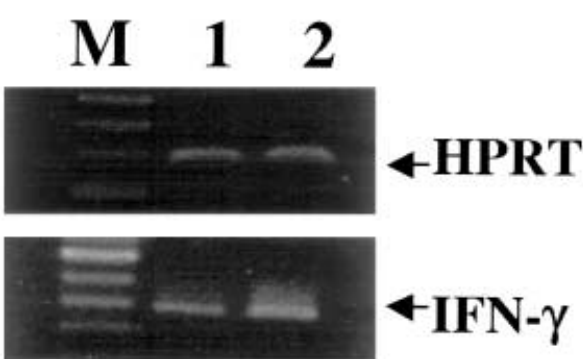
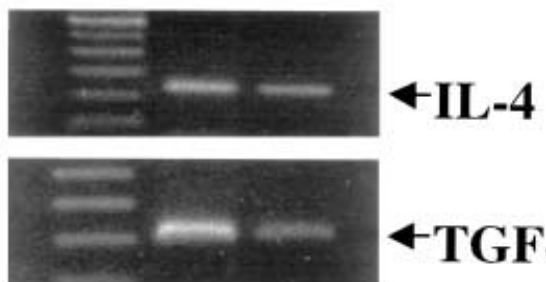

TGF- $\beta$

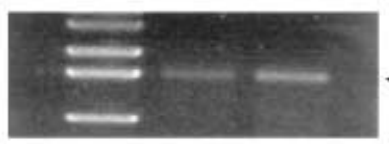

KRV

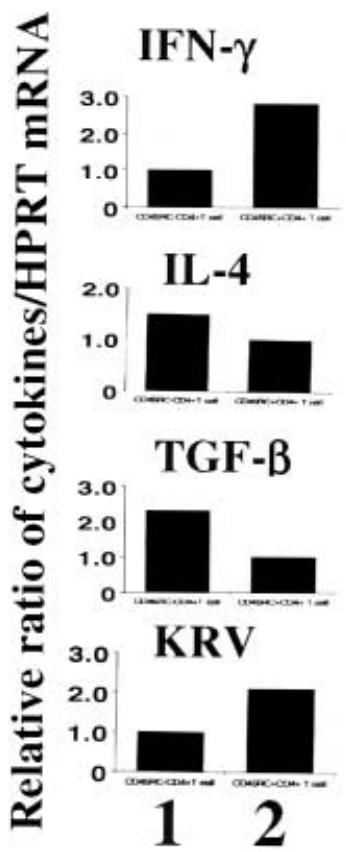

Fig. 6. A Upregulation of Th1-like $\mathrm{CD}^{+} \mathrm{T}$ cells and downregulation of Th2-like $\mathrm{CD}^{+}{ }^{+}$T cells in DR-BB rats during KRV infection. (A) Splenocytes were isolated from DR-BB rats at 7 days after KRV infection or PBS treatment ( $n=4 /$ group), labelled with biotin-conjugated OX-22 and streptavidin Red-613 and PE-conjugated OX-35 monoclonal antibody (mAb) and analysed on a flow cytometer. Representative data from two different experiments are shown. (B) After enrichment of the $\mathrm{CD} 4^{+} \mathrm{T}$ cells, the cells were sorted into CD45RC ${ }^{+} \mathrm{CD} 4^{+} \mathrm{T}$ cells and $\mathrm{CD} 45 \mathrm{RC}^{-} \mathrm{CD} 4^{+} \mathrm{T}$ cells. The purity of the sorted cells was examined using FACScan after staining of the cells with FITC-conjugated $\mathrm{OX}-22 \mathrm{mAb}$ and PE-conjugated $\mathrm{OX}$ $35 \mathrm{mAb}$. Cytokine and KRV-NS1 gene expression were measured by RT-PCR. Lane M, 100-bp DNA ladder for cytokine gene expression and 1-kb DNA ladder for KRV-NS1 gene expression. Lane 1, $\mathrm{CD} 45 \mathrm{RC}^{-} \mathrm{CD}^{+}{ }^{+} \mathrm{T}$ cells. Lane 2, CD45RC ${ }^{+} \mathrm{CD}^{+} \mathrm{T}$ cells tion. In addition, $\mathrm{CD}^{+} \mathrm{T}$ cells preferentially proliferated as compared with $\mathrm{CD} 4^{+} \mathrm{T}$ cells in $\mathrm{KRV}$-infected DR-BB rats. When KRV-infected DR-BB rats were treated with OX-8 monoclonal antibody, the incidence of diabetes in these rats was significantly decreased $(p<0.01)$, indicating that $\mathrm{CD}^{+} \mathrm{T}$ cells are clearly involved in the destruction of beta cells. It has been reported that the treatment of DP-BB rats with anti-NK cell antibody failed to prevent diabetes whereas OX-8 monoclonal antibody treatment successfully prevented diabetes [95]. Therefore, it is more likely that $\mathrm{CD}^{+} \mathrm{T}$ cells play a major part in KRV-induced diabetes, although the possibility of the involvement of NK cells cannot be absolutely excluded, because OX-8 monoclonal antibody also depletes NK cells.

In the rat, $\mathrm{CD}^{+}{ }^{+} \mathrm{T}$ cells can be divided into Th1like $\mathrm{CD} 45 \mathrm{RC}^{+} \mathrm{CD} 4^{+} \mathrm{T}$ cells, which express IL-2 and 
IFN- $\gamma$ and play an important part in cell-mediated immune responses, and Th2-like $\mathrm{CD}_{45 \mathrm{RC}^{-} \mathrm{CD} 4^{+} \mathrm{T}}$ cells, which express IL-4 and IL-10 and play an important part in humoral immune responses [96]. It has been suggested that the immune balance between Th1- and Th2-type cells plays an important part in the maintenance of peripheral tolerance. The dominance of Th1 cells over Th2 cells is associated with the development of autoimmune Type I diabetes, whereas the dominance of Th 2 cells over Th1 cells is associated with the prevention of Type I diabetes [97-99]. It was found previously that KRV infection in DR-BB rats increased the expression of Th1-type cytokines in the splenocytes and pancreatic infiltrates [66]. Therefore, it is possible that the proportions of Th1 and Th2 cells are altered during KRV infection in DR-BB rats. As expected, the number of Th2-like $\mathrm{CD}_{45 \mathrm{RC}^{-} \mathrm{CD}^{+}}{ }^{\mathrm{T}}$ cells was significantly decreased $(p<0.01)$ and the number of Th1-like $\mathrm{CD}_{45 \mathrm{RC}^{+} \mathrm{CD}^{+}}{ }^{+} \mathrm{T}$ cells significantly increased $(p<0.05)$ in the splenocytes of KRV-infected DRBB rats compared with PBS-treated controls (Fig. 6).

It seems clear that the infection of DR-BB rats with KRV results in the selective activation of Th1like $\mathrm{CD} 45 \mathrm{RC}^{+} \mathrm{CD} 4^{+} \mathrm{T}$ cells and $\mathrm{CD}^{+} \mathrm{T}$ cells. Thus, it was asked whether the selectively activated Th1like $\mathrm{CD} 45 \mathrm{RC}^{+} \mathrm{CD} 4^{+}$and $\mathrm{CD}^{+} \mathrm{T}$ cells could induce autoimmune diabetes in young DP-BB rats. Th1-like

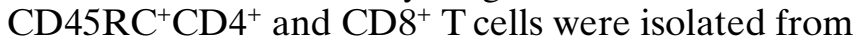
DR-BB rats after infection with KRV, stimulated with ConA, and transferred to young DP-BB rats. A total of $88 \%$ of the recipients of both $\mathrm{CD} 45 \mathrm{RC}^{+} \mathrm{CD} 4^{+}$ and $\mathrm{CD}^{+} \mathrm{T}$ cells developed autoimmune diabetes, indicating that $\mathrm{CD} 45 \mathrm{RC}^{+} \mathrm{CD} 4^{+}$and $\mathrm{CD}^{+} \mathrm{T}$ cells are major effector T cells that can induce autoimmune diabetes. The incidence of diabetes in DP-BB rats that received either $\mathrm{CD} 45 \mathrm{RC}^{+} \mathrm{CD} 4^{+}$or $\mathrm{CD} 8^{+} \mathrm{T}$ cells alone was, however, significantly decreased $(p<0.01)$ compared with that in rats that received a combination of $\mathrm{CD} 45 \mathrm{RC}^{+} \mathrm{CD}^{+}$and $\mathrm{CD}^{+} \mathrm{T}$ cells. A combination

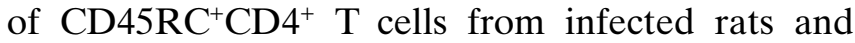
$\mathrm{CD} 8^{+} \mathrm{T}$ cells from uninfected rats or a combination of $\mathrm{CD}^{+} \mathrm{T}$ cells from infected rats and

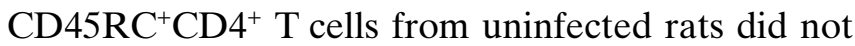
change the incidence of diabetes. These results indicate that Th1-like $\mathrm{CD}^{+}$and $\mathrm{CD}^{+} \mathrm{T}$ cells from $\mathrm{KRV}$-infected rats work synergistically to destroy beta cells, as proposed previously [66]. In contrast none of the recipients of both $\mathrm{CD} 45 \mathrm{RC}^{-} \mathrm{CD} 4^{+}$and $\mathrm{CD}^{+} \mathrm{T}$ cells developed diabetes, indicating that $\mathrm{CD}^{2} 5 \mathrm{RC}^{-} \mathrm{CD}^{+} \mathrm{T}$ cells play a part as regulatory $\mathrm{T}$ cells.

On the basis of these observations, it was concluded that the infection of DR-BB rats with KRV results in the preferential activation of effector $\mathrm{T}$ cells such as Th1-like $\mathrm{CD} 45 \mathrm{RC}^{+} \mathrm{CD} 4^{+} \mathrm{T}$ cells and $\mathrm{CD} 8^{+} \mathrm{T}$ cells and the downregulation of Th2-like $\mathrm{CD} 45 \mathrm{RC}^{+} \mathrm{CD} 4^{+}$ $\mathrm{T}$ cells, and that the activated effector $\mathrm{T}$ cells kill the beta cells, similar to the case in DP-BB rats. Therefore, infectious KRV, rather than KRV proteins expressed in recombinant vaccinia viruses, is absolutely required to disturb or breakdown the finely tuned immune balance, resulting in the upregulation of preexisting beta-cell-cytotoxic effector T cells.

\section{Conclusion}

Although a genetic predisposition seems to be necessary for the development of Type I diabetes, non-genetic environmental factors play an important part in the expression of the disease. Viruses, as one environmental factor, might be involved in the pathogenesis of Type I diabetes in at least two distinct ways. Firstly, viruses could directly infect and destroy beta cells or, secondly, viruses could in some way trigger beta-cell-specific autoimmunity and the autoimmune-mediated destruction of beta cells. The EMC$\mathrm{D}$ virus is a primary agent that is selectively injurious to beta cells and KRV is a triggering agent of betacell-specific autoimmunity that leads to Type I diabetes without the direct infection of the beta cells.

For EMC-D virus as a primary agent, two animal models have been established to study the pathogenic mechanisms involved in the destruction of beta cells. One model consists of mice infected with a high titre of EMC-D virus, in which diabetes develops as a result of the destruction of beta cells largely through the replication of the virus within the beta cells. The other model consists of mice infected with a low titre of EMC-D virus, in which diabetes develops by the destruction of beta cells through soluble mediators released from macrophages that the EMC virus infects and activates. From studies on low dose EMC$\mathrm{D}$ virus-induced diabetes, it was found that macrophage-derived soluble mediators, such as IL- $1 \beta$, TNF- $\alpha$ and iNOS, play a critical part in the destruction of beta cells in EMC-D virus-infected DBA/2 mice. In this latter model, the activated macrophages are major effectors that can kill beta cells. The tyrosine kinase signalling pathway is involved in the activation of macrophages by the EMC-D virus. Further studies found that signal transduction molecules, particularly a Src kinase, hck, are closely involved in macrophage activation. The treatment of EMC-D virus-infected mice with a Src kinase inhibitor, PP2, results in the inhibition of hck activity, a decrease in the production of TNF- $\alpha$ and iNOS in the macrophages and the subsequent prevention of diabetes. Further studies are needed to understand the molecular role of hck in the pathogenesis of EMC-D virus-induced diabetes using hck knockout mice.

The mechanism by which KRV, as a triggering agent for autoimmune diabetes, induced autoimmune Type I diabetes without the direct infection of beta cells was poorly understood. It had been suggest- 


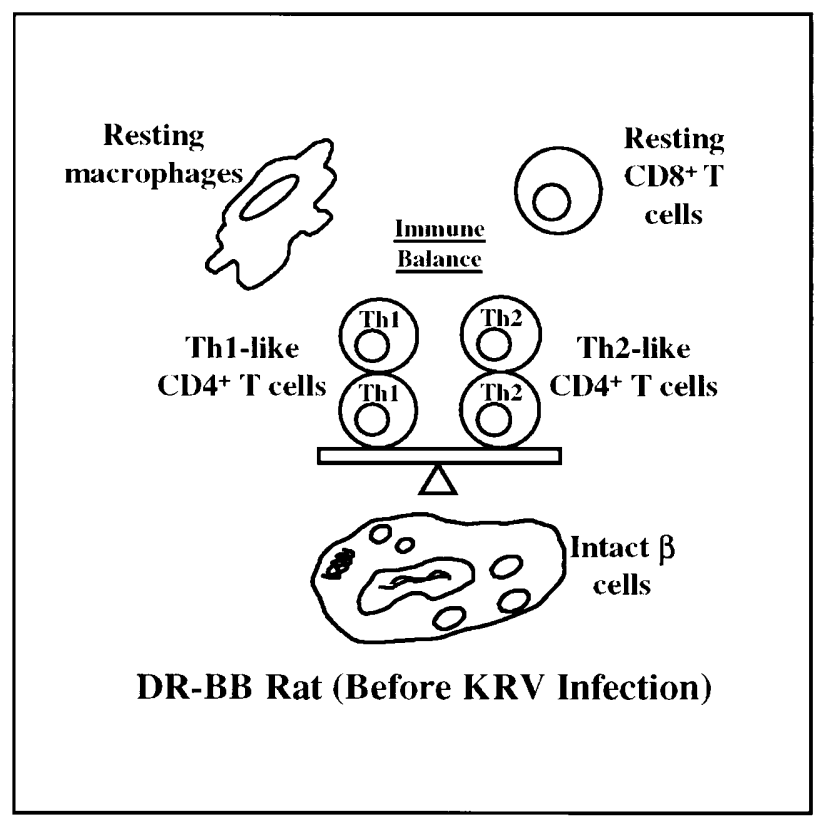

DR-BB Rat (Before KRV Infection)

Fig. 7. Schematic diagram of the possible mechanism for KRVinduced diabetes in DR-BB rats. In DR-BB rats, before infection with KRV, there is a solid immune balance between Th1type $\mathrm{CD}^{+}$and $\mathrm{Th} 2$-type $\mathrm{CD} 4^{+} \mathrm{T}$ cells. Pre-existing macrophages and $\mathrm{CD}^{+} \mathrm{T}$ cells are in the resting state. The infection of DR-BB rats with KRV results, however, in the preferential activation of Th1-type CD $4^{+} \mathrm{T}$ cells, which secrete IL-2 and IFN- $\gamma$. IL- 2 secreted from the activated Th1-type CD $4^{+} \mathrm{T}$ cells also activates $\mathrm{CD}^{+} \mathrm{T}$ cells. In addition, KRV activates macrophages which secrete IL-12, which also activates Th1-type $\mathrm{CD}^{+} \mathrm{T}$ cells. Thus, there is a substantial increase in Th1-type $\mathrm{CD}^{+} \mathrm{T}$ cells and, subsequently, an increase in $\mathrm{CD}^{+} \mathrm{T}$ cells. Through this process, the finely tuned immune balance can be broken down, resulting in the upregulation of effector $\mathrm{T}$ cells (Th1-type $\mathrm{CD}^{+}$and $\mathrm{CD}^{+} \mathrm{T}$ cells), leading to the destruction of beta cells

ed that molecular mimicry between KRV peptides and beta-cell-specific autoantigens might be a mechanism for the initiation of beta-cell-specific autoimmune diabetes in DR-BB rats. In this scenario, KRV antigen-specific $\mathrm{T}$ cells generated by KRV infection might attack beta cells if there is a common epitope between a KRV protein and an autoantigen expressed on beta cells. Alternatively, KRV infection of DR-BB rats might selectively activate beta-cell-cytotoxic effector T cells, resulting in T-cell-mediated autoimmune diabetes similar to that seen in DP-BB rats. This latter hypothesis suggests that KRV infection of DR-BB rats might activate silent autoreactive $\mathrm{T}$ cells, which are normally regulated by regulatory cells such as the RT6.1 $1^{+}$subset of T cells. The breakdown of the immune balance as a consequence of KRV infection might result in the selective activation of autoreactive T cells that are cytotoxic to beta cells, leading to autoimmune diabetes in DR-BB rats.

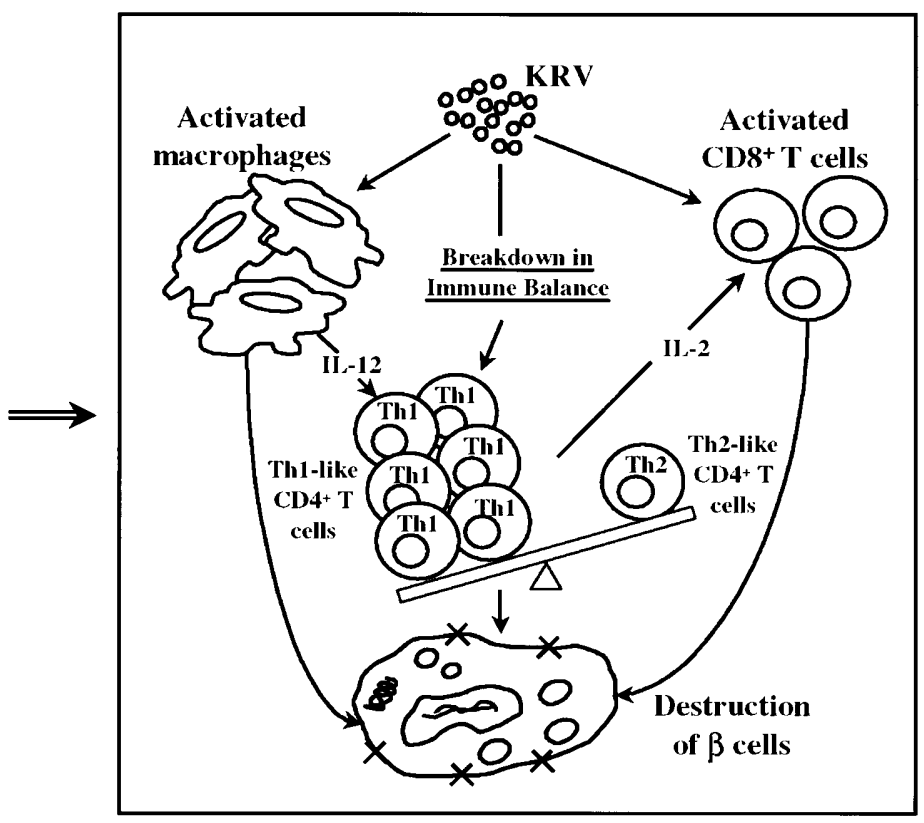

DR-BB Rat (After KRV Infection)

Through the results of a set of experiments designed to test these two hypotheses, it is concluded that $\mathrm{KRV}$-induced autoimmune diabetes in DR-BB rats is not due to molecular mimicry but due to the breakdown of the finely tuned immune balance of Th1-like $\mathrm{CD}_{45 \mathrm{RC}^{+} \mathrm{CD}^{+}}{ }^{+}$and Th2-like CD45RC- $\mathrm{CD}^{+}{ }^{+} \mathrm{T}$ cells, resulting in the selective activation of beta-cell-cytotoxic effector T cells (Fig.7). Further studies are needed, however, to understand the precise role of these effector T cells in the destruction of beta cells and the development of these cells in KRV-infected DR-BB rats.

\section{References}

1. Lernmark A, Falorni A (1997) Immune phenomena and events in the islets in insulin-dependent diabetes mellitus. In: Pickup JC, Williams G (eds) Textbook of Diabetes (2nd ed.) Blackwell Science, Oxford, pp 15.1-15.23

2. Yoon JW, Jun HS (1998) Insulin-dependent diabetes mellitus. In: Roitt IM, Delves PJ (eds) Encyclopedia of Immunology (2nd ed.) Academic Press Ltd, London, pp 1390-1398

3. Rossini AA, Greiner DL, Friedman HP, Mordes JP (1993) Immunopathogenesis of diabetes mellitus. Diabetes Rev 1: $43-75$

4. Atkinson MA, McLaren NK (1994) The pathogenesis of insulin-dependent diabetes mellitus. N Engl J Med 331: 1428-1436

5. Bach JF (1995) Insulin-dependent diabetes mellitus as a $\beta$ cell targeted disease of immunoregulation. J Autoimmun 8: 439-463

6. Verge CF, Eisenbarth GS (1996) Prediction of type I diabetes: the natural history of the prediabetic period. In: Eisenbarth GS, Lafferty KJ (eds) Type I Diabetes: Molecular, Cellular and Clinical Immunology. Oxford University Press, New York, pp 230-258

7. Tisch R, McDevitt H (1996) Insulin-dependent diabetes mellitus. Cell 85: 291-297 
8. Brooks-Worrell BM, Starkebaum GA, Greenbaum C, Palmer JP (1996) Peripheral blood mononuclear cells of insulin-dependent diabetic patients respond to multiple islet cell proteins. J Immunol 157: 5668-5674

9. Todd JA, Bain SC (1992) A practical approach to identification of susceptibility genes for IDDM. Diabetes 41: 1029-1034

10. She JX (1996) Susceptibility to type 1 diabetes: HLA-DQ and DR revisited. Immunology Today 17: 323-329

11. Nerup J, Platz P, Anderssen OO (1974) HL-A antigens and diabetes mellitus. Lancet ii: $864-866$

12. Platz P, Jakobsen BK, Morling M et al. (1981) HLA-D and DR-antigens in genetic analysis of insulin-dependent diabetes mellitus. Diabetologia 21: 108-115

13. Horn G, Bugawa T, Long C, Erlich H (1988) Allelic sequence of the HLA-DQ loci: relationship to serology and to insulin-dependent diabetes susceptibility. Proc Natl Acad Sci USA 85: 6012-6016

14. Segall M (1988) HLA and the genetics of IDDM: holism versus reductionism. Diabetes 37: 1005-1008

15. Sheehy M, Scharf S, Rowe J et al. (1989) A diabetes-susceptible HLA haplotype is best defined by a combination of HLA-DR and DQ alleles. J Clin Invest 83: 830-835

16. Serreze DV, Leiter EH (1994) Genetic and pathogenic basis of autoimmune diabetes in NOD mice. Curr Opin Immunol 6: 900-906

17. Acha-Orbea H, McDevitt HO (1987) The first external domain of the nonobese diabetic mouse class II I-A $\beta$ chain is unique. Proc Natl Acad Sci USA 84: 2435-2439

18. Barnett AH, Eff C, Leslie RD, Pyke DA (1981) Diabetes in identical twins. A study of 200 pairs. Diabetologia 20: 87-93

19. Yoon JW (1997) Pathogenesis of IDDM: Environmental Factors. In: Pickup J, Williams G (eds) Textbook of Diabetes. Blackwell Scientific Publications, London, pp 14.1-14.14

20. Yoon JW, Kim AM, Jun HS (1999) Role of viruses in insulin-dependent diabetes mellitus. In: Turtle JR (ed) Diabetes in the New Millennium. Endocrinology and Diabetes. Research Foundation of the University of Sydney, Sydney, Australia. pp 105-117

21. Adams SF (1926) The seasonal variation in the onset of acute diabetes. Arch Intern Med 27: 861-862

22. Notkins AL, Yoon JW, Onodera T, Jenson AB (1981) Virus-induced diabetes. Perspectives Virol 11: 141-162

23. Yoon JW, Austin M, Onodera T, Notkins AL (1979) Isolation of a virus from the pancreas of a child with diabetic ketoacidosis. N Engl J Med 300: 1173-1179

24. Champsaur HF, Bottazzo GF, Bertrams J, Assan R, Bach C (1982)Virologic, immunologic and genetic factors in insulin-dependent diabetes mellitus. J Pediatrics 100: 15-20

25. Yoon JW, Kominek HI (1996) Role of Coxsackie B viruses in the pathogenesis of diabetes mellitus. In: Rose NR, Friedman $\mathrm{H}$ (eds) Microorganisms and Autoimmune Diseases. Plenum Press, New York, pp 129-158

26. King ML, Shaikh A, Bidwell D, Voller A, Banatvala JE (1983) Coxsackie B-virus specific IgM responses in children with insulin-dependent diabetes mellitus. Lancet i: 1397-1399

27. Banatvala JE, Schernthaner G, Schober E, et al. (1985) Coxsackie B, mumps, rubella and cytomegalovirus specific $\mathrm{IgM}$ responses in patients with juvenile-onset insulin-dependent diabetes mellitus in Britain, Austria and Australia. Lancet i: $1409-1412$

28. Friman G, Fohlman J, Frisk G et al. (1985) An incidence peak of juvenile diabetes. Relation to Coxsackie B virus immune response. Acta Pediatr Scand 320 [Suppl]: 14-19
29. Szopa TM, Titchener PA, Portwood ND, Taylor KW (1993) Diabetes mellitus due to viruses - some recent developments. Diabetologia 36: 687-695

30. Gladisch R, Hoffmann W, Waldherr R (1976) Myocarditis and insulitis following Coxsackie virus infection. Z Kardiol 65: 837-849

31. Jensen A, Rosenberg H, Notkins AL (1980) Virus-induced diabetes mellitus XVII: pancreatic islet cell damage in children with fatal viral infections. Lancet ii: $354-358$

32. Ginsberg-Fellner F, Fedun B, Cooper Z et al. (1986) Interrelationships of congenital rubella and type 1 insulin-dependent diabetes mellitus. In: Jaworski MA, Molnar GD, Rajotte RV, Singh B (eds) The Immunology of Diabetes Mellitus. Elsevier, Amsterdam, pp 279-286

33. Ginsberg-Fellner F, Witt ME, Yagihaski S (1984) Congenital rubella-syndrome as a model for type 1 (insulin-dependent) diabetes mellitus: increased prevalence of islet cell surface antibodies. Diabetologia 27: 87-89

34. Gamble DR (1980) Relation of antecedent illness to development of diabetes in children BMJ 2: 99-101

35. Helmke K, Otten A, Willems W (1980) Islet cell antibodies in children with mumps infection. Lancet ii: 211-212

36. Ward KP, Galloway WH, Auchterlonie IA (1979) Congenital cytomegalovirus infection and diabetes. Lancet i: 497

37. Yasumoto N, Hara M, Kitamoto YU, Nakayama M, Sato T (1992) Cytomegalovirus infection associated with acute pancreatitis, rhabdomyolysis and renal failure. Intern Med 31: 426-430

38. Pak CY, Eun HM, McArthur RG, Yoon JW (1988) Association of cytomegalovirus infection with autoimmune type 1 diabetes. Lancet ii: $1-4$

39. Chikazawa K, Okusa H, Minakami H, Kimura K, Araki S, Tamada T (1985) Acute onset of insulin-dependent diabetes mellitus caused by Epstein-Barr virus infection. Acta Obstet Gynaecol Jpn 37: 1493-1501

40. Surcel HM, Ilonen J, Kaar ML, Hyöty H, Leinikki P (1988) Infection by multiple viruses and lymphocyte abnormalities at the diagnosis of diabetes. Acta Paediatr Scand 77: 471-474

41. Jali MV, Shankar PS (1990) Transient diabetes following chicken pox. J Assoc Physicians India 38: 663-664

42. Craighead JE, McLane MF (1968) Diabetes mellitus: Induction in mice by encephalomyocarditis virus. Science 162: 913-915

43. Yoon JW, McClintock PR, Onodera T, Notkins AL (1980) Virus-induced diabetes mellitus. XVIII. Inhibition by a nondiabetogenic variant of encephalomyocarditis virus. J Exp Med 152: 878-892

44. Yoon JW, Morishima T, McClintock PR, Austin M, Notkins AL (1984) Virus-induced diabetes mellitus: mengovirus infects pancreatic beta cells in strains of mice resistant to encephalomyocarditis virus. J Virol 50: 684-690

45. Onodera T, Jenson AB, Yoon JW, Notkins AL (1978) Virus-induced diabetes mellitus: reovirus infection of pancreatic beta cells in mice. Science 301: 529-531

46. Suenaga K, Yoon JW (1988) Association of beta cell-specific expression of endogenous retrovirus with the development of insulitis and diabetes in NOD mice. Diabetes 37: 1722-1726

47. Gaskins H, Prochazka M, Hamguchi K, Serreze D, Leiter E (1992) Beta cell expression of endogenous xenotropic retrovirus distinguishes diabetes-susceptible NOD/Lt from resistant NON/Lt mice. J Clin Invest 90: 2220-2227

48. Nakagawa C, Hanafusa T, Miyagawa J et al. (1992) Retrovirus gag protein p30 in the islets of nonobese diabetic mice: relevance for pathogenesis of diabetes mellitus. Diabetologia 35: 614-618 
49. Yoon JW, Onodera T, Notkins AL (1978) Virus-induced diabetes mellitus. XV. Beta cell damage and insulin-dependent hyperglycemia in mice infected with Coxsackie virus B4. J Exp Med 148: 1068-1080

50. Hou J, Sheikh S, Martin DL, Chatterjee NK (1993) Coxsackie virus B4 alters pancreatic glutamic decarboxylase expression in mice soon after infection. $\mathrm{J}$ Autoimmun 6: 529-542

51. Yoon JW, London WT, Curfman BL, Brown RL, Notkins AL (1986) Coxsackie virus B4 produces transient diabetes in nonhuman primates. Diabetes 35: 712-716

52. Barboni E, Manocchio I, Asdrubali G (1966) Observations on diabetes mellitus associated with experimental footand-mouth disease in cattle. Arch Vet Ital 17: 362-368

53. Menser MA, Forrest JM, Bransby RD (1978) Rubella infection and diabetes mellitus. Lancet i: 57-60

54. Rayfield E, Kelly K, Yoon JW (1986) Rubella virus-induced diabetes in hamsters. Diabetes 35: 1276-1281

55. Tajima M, Yazawa T, Hagiwara K, Kurosawa T, Takahashi K (1992) Diabetes mellitus in cattle infected with bovine viral diarrhea mucosal disease virus. Zentralbl Veterinarmed 39: 616-620

56. Guberski DL, Thomas VA, Shek WR et al. (1991) Induction of type I diabetes by Kilham's rat virus in diabetes-resistant BB/Wor rats. Science 254: 1010-1013

57. von Herrath MG, Holz A, Homann D, Oldstone MB (1998) Role of viruses in type I diabetes. Semin Immunol 10: $87-100$

58. von Herrath MG, Oldstone MB (1996) Virus-induced autoimmune disease. Curr Opin Immunol 8: 878-885

59. Oldstone MB (1998) Molecular mimicry and immune-mediated diseases. FASEB J 12: 1255-1265

60. Dyrberg T, Schwimmbeck PL, Oldstone MBA (1988) Inhibition of diabetes in BB rats by viral infection. J Clin Invest 81: 928-931

61. Wilberz S, Partke HJ, Dagnaes-Hansen F, Herberg L (1991) Persistent MHV (mouse hepatitis virus) infection reduces the incidence of diabetes mellitus in non-obese diabetic mice. Diabetologia 34: 2-5

62. Yoon JW, Lesniak MA, Fussganger R, Notkins AL (1976) Genetic differences in susceptibility of pancreatic $\beta$-cells to virus-induced diabetes mellitus. Nature 264: 178-180

63. Yoon JW, Rodrigues MM, Currier C, Notkins A (1982) Long-term complications of virus-induced diabetes mellitus in mice. Nature 296: 566-569

64. Brown DW, Welsh RM, Like AA (1993) Infection of peripancreatic lymph nodes but not islets precedes Kilham rat virus-induced diabetes in $\mathrm{BB} /$ Wor rats. J Virol 67: 5873-5878

65. Ellerman KE, Richards CA, Guberski DL, Shek WR, Like AA (1996) Kilham rat virus triggers T-cell-dependent autoimmune diabetes in multiple strains of rat. Diabetes 45: $557-562$

66. Chung YH, Jun HS, Hirasawa K, Lee BR, van Rooijen N, Yoon JW (1997) Role of macrophages and macrophage-derived cytokines in the pathogenesis of Kilham rat virus-induced autoimmune diabetes in diabetes-resistant BB rats. J Immunol 159: 466-471

67. Chung YH, Jun HS, Son M, Bao M, Bae HY, Kang Y, Yoon JW (2000) Cellular and molecular mechanism for Kilham rat virus-induced autoimmune diabetes in DR-BB rats. J Immunol 165: 2866-2876

68. Ross ME, Onodera T, Brown KS, Notkins AL (1976) Virus-induced diabetes mellitus. IV. Genetic and environmental factors influencing the development of diabetes after infection with the $\mathrm{M}$ variant of encephalomyocarditis virus. Diabetes 25: 190-197
69. Yoon JW, Onodera T, Notkins AL (1977) Virus-induced diabetes mellitus. IX. Studies on virus passage and dose in susceptible and resistant strains of mice. J Gen Virol 27: 225-232

70. Bae YS, Eun HM, Yoon JW (1989) Molecular identification of viral gene. Diabetes 38: 316-320

71. Bae YS, Eun HM, Yoon JW (1989) Genomic differences between the diabetogenic and non-diabetogenic variants of encephalomyocarditis virus. Virology 170: 282-287

72. Bae YS, Yoon JW (1993) Determination of diabetogenicity attributable to a single amino acid, Ala-776, on the polyprotein of encephalomyocarditis virus. Diabetes 42: 435-443

73. Bae YS, Kang Y, Otsuka E, Yoon JW (1993) Development of a recombinant RNA technique for the construction of chimeric RNA with a long $\operatorname{poly}(\mathrm{C})$ tract. Nucleic Acids Res 21: 2703-2708

74. Jun HS, Kang Y, Notkins AL, Yoon JW (1997) Gain or loss of diabetogenicity resulting from a single point mutation in recombinant encephalomyocarditis virus. J Virol 71: 9782-9785

75. Eun HM, Bae YS, Yoon JW (1988) Amino acid differences in capsid protein, VP1, between diabetogenic and nondiabetogenic variants of encephalomyocarditis virus. Virology 163: 369-373

76. Kaptur PE, Thomas DC, Giron DJ (1989) Differing attachment of diabetogenic and nondiabetogenic variants of encephalomyocarditis virus to beta cells. Diabetes 38: 1103-1108

77. Jun HS, Kang Y, Yoon HS, Kim KH, Notkins AL, Yoon JW (1998) Determination of encephalomyocarditis viral diabetogenicity by a putative binding site of the viral capsid protein. Diabetes 47: 576-582

78. Onodera T, Yoon JW, Brown KS, Notkins AL (1978) Evidence for a single locus controlling susceptibility to virusinduced diabetes mellitus. Nature 274: 693-696

79. Kang Y, Yoon JW (1993) A genetically determined host factor controlling susceptibility to encephalomyocarditis virus-induced diabetes in mice. J Gen Virol 74: 12071213

80. Yoon JW, McClintock PR, Bachurski CJ, Longstreth JD, Notkins AL (1985) Virus-induced diabetes: No evidence for immune mechanisms in the destruction of beta cells by the D variant of encephalomyocarditis virus. Diabetes 34 : 922-925

81. Baek HS, Yoon JW (1990) Role of macrophages in the pathogenesis of encephalomyocarditis virus-induced diabetes in mice. J Virol 64: 5708-5715

82. Baek HS, Yoon JW (1991) Direct involvement of macrophages in destruction of $\beta$-cells leading to development of diabetes in virus-infected mice. Diabetes 40: 1586-1597

83. Hirasawa K, Jun HS, Han HS, Zhang M-L, Hollenberg M, Yoon JW (1999) Prevention of encephalomyocarditis virus-induced diabetes in mice by inhibition of the tyrosine signalling pathway and suppression of nitric oxide production in macrophages. J Virol 73: 8541-8548

84. Hirasawa K, Jun HS, Maeda K et al. (1997) Possible role of macrophage-derived soluble mediators in the pathogenesis of encephalomyocarditis virus-induced diabetes in mice. J Virol 71: 4024-4031

85. Fehsel K, Jalowy A, Sun Q, Burkart V, Hartmann B, Kolb $\mathrm{H}$ (1993) Islet cell DNA is a target of inflammatory attack by nitric oxide. Diabetes 42: 496-500

86. Rabinovitch A, Suarez-Pinzon WL, Shi Y, Morgan AR, Bleackley RC (1994) DNA fragmentation is an early event in cytokine-induced islet beta-cell destruction. Diabetologia 37: 733-738 
87. Kaneto H, Fujii J, Seo HG et al. (1995) Apoptotic cell death triggered by nitric oxide in pancreatic $\beta$-cells. Diabetes 44: 733-738

88. Firestein GS, Yeo M, Zvaifler NJ (1995) Apoptosis in rheumatoid arthritis synovium. J Clin Invest 96: 1631-1638

89. Marliss EB (1983) The Juvenile Diabetes Foundation workshop on spontaneously diabetic BB rat as potential for insight into human juvenile diabetes. Metab Clin Exp 32 [Suppl 1]: 1-166

90. Doukas J, Mordes JP, Swymer C et al. (1994) Thymic epithelial defects and predisposition to autoimmune disease in BB rats. Am J Pathol 145: 1517-1525

91. Greiner DL, Mordes JP, Handler ES, Angelillo M, Nakamura N, Rossini AA (1987) Depletion of RT6.1 ${ }^{+}$T lymphocytes induces diabetes in resistant BioBreeding/Worcester (BB/W) rats. J Exp Med 166: 461-475

92. Hany M, Oehen S, Schulz M et al. (1989) Anti-viral protection and prevention of lymphocytic choriomeningitis or of the local footpad swelling reaction in mice by immunization with vaccinia-recombinant virus expressing LCMVWE nucleoprotein or glycoprotein. Eur J Immunol 19: 417-424

93. Sutter G, Wyatt LS, Foley PL, Bennick JR, Moss B (1994) A recombinant vector derived from the host-restricted and highly attenuated MVA strain of vaccinia virus stimulates protective immunity in mice to influenza virus. Vaccine 12: 1032-1040

94. Moss B (1996) Genetically engineered poxvirus for recombinant gene expression, vaccination, and safety. Proc Natl Acad Sci USA 93: 11341-11348

95. Ellerman K, Wrobleski M, Rabinovitch A, Like A (1993) Natural killer cell depletion and diabetes mellitus in the BB/Wor rat (revisited). Diabetologia 36: 596-601

96. Fowell D, McKnight AJ, Powrie F, Dyke R, Mason DW (1991) Subsets of CD4 ${ }^{+}$T cells and their roles in the induction and prevention of autoimmunity. Immunol Rev 123: 37-64

97. Rabinovitch A (1994) Immunoregulatory and cytokine imbalances in the pathogenesis of IDDM: therapeutic intervention by immunostimulation? Diabetes 43: 613-621

98. Liblau RS, Singer SM, McDevitt HO (1995) Th1 and Th2 $\mathrm{CD}^{+} \mathrm{T}$ cells in the pathogenesis of organ-specific autoimmune disease. Immunol Today 16: 34-38

99. Delovitch T, Singh B (1997) The nonobese diabetic mouse as a model of autoimmune disease: immune dysregulation gets the NOD. Immunity 7: 727-738 